\title{
EXPERIMENTAL STUDY ON THE EFFECT OF CAPILLARY TUBE GEOMETRY ON THE PERFORMANCE OF VAPOUR COMPRESSION REFRIGERATION SYSTEM
}

\author{
Abdul- Kareem R. Abed ${ }^{1}$, Hassan Jawdat Fadhiel ${ }^{2}$, Gaydaa Mahsun ${ }^{3}$, Thabet C. Yassen ${ }^{4}$ \\ ${ }^{1,2}$, Assistant lecturer ${ }^{3,4}$ Engineer \\ Technical College - Baghdad, Iraq \\ (Received: 5/12/2012; Accepted:27 /3/2013)
}

\begin{abstract}
A domestic refrigerator of $5 \mathrm{ft}^{3}$ capacity is used to study the effect of coiled diameter and pitch distance of a capillary tube. Five capillary tubes of $2 \mathrm{~mm}$ in diameter and $1500 \mathrm{~mm}$ length each are used, as same as original capillary tube of the refrigerator. The capillary tubes is formed in five shapes, each one has different coil diameter (D) namely 25, 50, 75, 100 and $125 \mathrm{~mm}$ in diameter, in addition three distances between each coil (pitch (P)) is tested, namely 6,8 and $10 \mathrm{~mm}$. The pressure at inlet and outlet of capillary are measured to calculate the cycle COP, as well as the power consumed by the cycle compressor is measured to calculate the mass flow rate of refrigerant. The work show that the coiled diameter of capillary tube affect the cycle COP strongly, as the capillary coiled diameter (D) increases from 25 to $100 \mathrm{~mm}$ the cycle COP increases from 2.8 to 3.7 when the cabinet temperature equals to $8^{\circ} \mathrm{C}$. The increases of coiled diameter more than $100 \mathrm{~mm}$ shows insignificant effect on the cycle COP. While the pitch space of capillary tube coiled shows minor effect on the cycle COP. Moreover, to the mass flow rate of refrigerant increases with approximately ranges from $1.2-2.7 \mathrm{~g} / \mathrm{s}$ as the capillary coiled diameter increases from 25 to $125 \mathrm{~mm}$ when the cabinet temperature equals to $8^{\circ} \mathrm{C}$. Also; there are directly proportional between the temperature of evaporator cabinet from $2-8{ }^{\circ} \mathrm{C}$ with mass flow rate of refrigerant from $1.9-2.4 \mathrm{~g} / \mathrm{s}$ when capillary coiled diameter $100 \mathrm{~mm}$.
\end{abstract}

Key words: vapour compression cycle, capillary tube, and capillary tube geometry.

\section{INTRODUCTION}

Hermetic compressors are almost universally used in small systems such as domestic refrigerators, water coolers, air conditioners and deep freezer, where efficiency is not as important as customer convenience. In addition to this, the use of hermetic compressors is ideal in systems, which use capillary tubes as expansion devices to reduce the pressure in 
evaporator section. In capillary tube the refrigerant has to overcome the frictional resistance offered by tube walls which leads to some pressure drop, and also the liquid refrigerant flashes into wet vapour, as its pressure reduces through the capillary tube. Both variables mentioned above increase the pressure drop across the capillary tube, this pressure drop controls the mass flow rate of refrigerant, and for a given value of condenser pressure, there is a definite value of evaporator pressure at which the mass flow rates through the compressor and the evaporator are the same. Thus the mass flow rate through the capillary tube increases as the condenser pressure increases and/or the evaporator pressure decreases. One of the most variables affect the pressure drop across a given capillary tube is the capillary geometry, like the number of coils and pitch between the coils [1].

Kim, S.G. et al. [2] presented test results for straight capillary tubes were also compared with those of different coiled radius capillary tubes (40, 120 and 200mm). The mass flow rates for coiled capillary tubes are quite reduced when compared with those for straight capillary tubes especially for the cases where the coiled diameter is reduced. The mass flow rates in capillary tubes with coiled diameter of $40 \mathrm{~mm}$ are approximately $9 \%$ less than those of straight capillary tubes.

Wei, C.Z. et al. (2001) [3] studied the performance of capillary tubes for R-407C refrigerant. In their study a total of nine capillary tubes were tested. The capillary tubes consisted of straight and coiled configurations. The geometry of the capillary tubes used was: length $(1,000 \mathrm{~mm})$, internal diameter $(1.0 \mathrm{~mm})$ and two coiled diameters of 52 and $130 \mathrm{~mm}$. comparing the flow rate of the coiled configuration with that of straight capillary tube, for the same inlet and out let pressures, tube diameter and length, the mass flow rate decreases with decrease in coiled diameter.

M.K. Mittal. et al. (2010) [4] This paper presents an experimental investigation of coiling effect on the flow of R-407C in an adiabatic helical capillary tube. It has been observed that the coiling of capillary tube significantly influences the mass flow rate of R407C through the adiabatic helical capillary tube. For the sake of comparison, the experiments have also been conducted for straight capillary tube and it has been observed that the mass flow rates in coiled capillary tube are 5-10 percent less than those in a straight one. Parametric study has been conducted for the mass flow rate of R-407C through the capillary tubes of straight and coiled geometry. As compared to the mass flow rate of $\mathrm{R}-407 \mathrm{C}$ in straight capillary tube, the mass flow rate in coiled capillary with coil diameter of $60 \mathrm{~mm}$, $100 \mathrm{mmand} 140 \mathrm{mmis}$ reduced by an average of 10 percent, 7 percent and 5 percent respectively. 
Mutalubi Arremu akintunde (2007) [5] reported the effect of pitch of both helical and serpentine- coiled capillary tubes on the performance of vapour compression refrigeration system of $10 \mathrm{~kW}$ capacity that uses R-134a as the working refrigerant. The effects of helicalcoiled capillary tubes with those of serpentine- coiled capillary tubes were compared. Five different types of helical-coiled capillary tube were used for this purpose. The coefficient of correlations are: 0.9841 for mass flow rates of helical and serpentine with straight tubes; 0.9864 for corresponding COPs and 0.9996 for mass flow rates of serpentine and helicalcoiled tube.

Mohd. Kaleem Khan et al. (2008) [6] Investigated experimentally the flow characteristics of refrigerant R-134a through an adiabatic helically coiled capillary tube. The effect of various physical parameters, like diameter and length of capillary tube, coil pitch, and inlet sub-cooling on the mass flow rate of R-134a. Moreover, the refrigerant mass flow rate through an instrumented capillary tube was also compared to that through a noninstrumented capillary tube. It was found that the provision of taps for pressure measurement on the capillary tube surface has a negligible effect on the mass flow rate of R-134a. Further, the coil pitch had a significant effect on the performance of the adiabatic helically coiled capillary tube. It was established that the coil pitch significantly influenced the mass flow rate through the adiabatic helically coiled capillary tube. It was concluded that the effect of coiling of the capillary tube reduces the mass flow rate by $5 \%$ to $15 \%$, as compared to those of the straight capillary tube operating under similar conditions. The data obtained from the experiments were analyzed, and a semi-empirical correlation was developed. Almost 97\% of the mass flow rate predicted by the proposed correlation lies in the error band of $\pm 10 \%$.

Sukkarin et al. (2010) [7] this paper presented the effects of various geometries of helical capillary tubes on the flow characteristics of alternative refrigerants flowing through adiabatic helical capillary tubes. The model was validated by comparing it with the experimental data of published in literature for R-22, particularly various pairs of refrigerants. The results shown that coil diameter variation (less than $300 \mathrm{~mm}$ ) for helical capillary tube geometries affected the length of helical capillary tubes. However, pitch variation (more than $300 \mathrm{~mm}$ ) had no significant effect on the length of helical capillary tubes.

\section{1- AIM OF THE WORK:}

The aim of this work is to investigate the effect of the pitch and coil diameter of helical coiled capillary tubes on the coefficient performance of vapour compression cycle and the mass flow rate of refrigerant. 


\section{2- APPARATUS SETUP}

The apparatus consist of a domestic refrigerator of $5 \mathrm{ft} 3$ capacity, as shown in figure (1), the connections between compressor section port, evaporator exit, capillary tube and evaporator inlet are modified to give an easy way to connect the tested capillary tube under study to the vapour compression cycle, as shown in figure (2). Two manual valves, service valve and flair and net connections are used to replace and remove the tested capillary tube. The manual valves are used to insulate the cycle from capillary tube to ensure that no refrigerant is escaped during capillary tube replacement. to ensure that no refrigerant is lost from the cycle, during replacement of capillary tube, manual valve 1 is closed while the refrigerator is in the ON mode. The liquid refrigerant is stored in the condenser, after that valve 3 is closed and then shut down the compressor. Then the refrigeration cycle is isolated, the capillary tube removed and new one is replaced, then the section between the two manual valves is evacuated through the service valve using a vacuum pump.

\section{3- TEST PROCEDUERS}

A $12 \mathrm{~g}$ of R-134a is added to the original charge of the refrigerator that equal to $63 \mathrm{~g}$ to overcome the increases pipe length that added to the cycle, then the total mass of R-134a in the cycle is equal to $75 \mathrm{~g}$. Five capillary tubes of $2 \mathrm{~mm}$ in diameter and $1500 \mathrm{~mm}$ length each are used, as same as original capillary tube of the refrigerator. The capillary tubes is formed in five shaped, each one has different coil diameter namely 25, 50, 75, 100 and $125 \mathrm{~mm}$ in diameter (D), in addition three distances between each coil (pitch) is tested, namely 6, 8 and $10 \mathrm{~mm}(\mathrm{P})$ as shown in figure (3). Thus fifteen types of capillary tube are tested in this work as shown in table 1 .

The coil pitch is changed for each type of capillary tube when it is installed within the refrigeration cycle, i.e. the capillary tube is changed only five times during the whole reading. Temperatures are measured at five points as shown in figure 1, using type (T) thermocouple and calibrated within the range of -20 to $100{ }^{\circ} \mathrm{C}$, while the high and low side pressures are measured at two points as shown in figure 1, using the manifold gauge.

\section{4- METHOD OF CALCULATION:}

The aim of this part is to analysis the vapour compression system is based on the steady flow energy equation and pressure-enthalpy Diagram of R-143a (to evaluate the values of enthalpy of each points require), to study the key variables, namely, COP, power of compressor, enthalpy of each points and mass flow rate of refrigerant; therefore, many 
measured variables ,namely, the refrigerant temperatures of each of inlet \& outlet compressor $\left(T_{1} \& T_{2}\right)$, outlet condenser $T_{3}$, inlet \& outlet evaporator $T_{1} \& T_{4}$ and evaporator cabinet, as shown in Figure (2) and (4). Also it measured high \& low pressure of vapor compression cycle and electrical voltage \& current consumed by compressor that were used in this unit.

- Compression process: To evaluate the work done in compression for this actual case is given by the enthalpy increase across the compressor can expressed in Eq.(1), [1] :

where:

$$
\mathrm{w}_{\text {comp. }}=\mathrm{h}_{2}-\mathrm{h}_{1} \quad(\mathrm{~kJ} / \mathrm{kg})
$$

$w_{\text {comp. }}$ :work done in compression $(\mathrm{kJ} / \mathrm{kg})$

$\mathrm{h}_{2}$ : enthalpy of outlet refrigerant from comressor $(\mathrm{kJ} / \mathrm{kg})$

$\mathrm{h}_{1}$ : enthalpy of inlet refrigerant to comressor $(\mathrm{kJ} / \mathrm{kg})$

- To evaluate the refrigerant effect which is the enthalpy change across the evaporator. this is expressed by Eq.(2), [1]:

where:

$$
\mathrm{RE}=\mathrm{h}_{1}-\mathrm{h}_{4} \quad(\mathrm{~kJ} / \mathrm{kg})
$$

RE: refrigerating effect in evaporator $(\mathrm{kJ} / \mathrm{kg})$

$$
\mathrm{h}_{4} \text { : enthalpy of inlet refrigerant to evaporator }(\mathrm{kJ} / \mathrm{kg} \text { ) }
$$

- The performance ratio of refrigeration system is not the efficiency, but rather the

Coefficient Of Performance, and define as the refrigeration effect (heat absorbed) divided by the net work done on the cycle (work input) as following[1]:

$$
\mathrm{COP}=\frac{\mathrm{RE}}{\mathrm{w}_{\text {comp. }}}
$$

where:

$$
\text { COP: Coefficient of performance of vapour compression unit. }
$$

- To evaluate Power consumed by the compressor as following equation, [1]:

where:

$$
P_{\text {comp. }}=\frac{V \times I}{1000}
$$

P: Power consumed by the compressor (Watt)

I: Ammeter reading (Amp.)

$\mathrm{V}$ : Voltage drop across the compressor (Volt)

- To calculate the value of mass flow rate of refrigerant used the equation (5), [1]:

where:

$$
\mathrm{m}_{\mathrm{R}}=\frac{\mathrm{P}_{\text {comp. }}}{\mathrm{w}_{\text {comp. }}} \quad(\mathrm{kg} / \mathrm{s})
$$

$\mathrm{m}_{\mathrm{R}}$ : Mass flow rate of refrigerant $(\mathrm{kg} / \mathrm{s})$

\section{5- RESULTS AND DISCUSSION:}

A capillary tube of $2 \mathrm{~mm}$ in diameter and $1500 \mathrm{~mm}$ long is formed to have five coil diameters and three pitches between coiled. To study the effect of pitch distance $(\mathrm{P})$ and coiled diameter (D) on the COP of domestic refrigerator. The voltage and power consumption are measured to estimate the mass flow rate of refrigerant.

Figure 5 shows the effect of coiled pitch on the cycle COP at different refrigerator cabinet temperature, when the capillary coiled diameter is $25 \mathrm{~mm}$. It can be seen from the 
figure that as the pitch distance between the coiled circuit increases from $P_{2}$ to $P_{3}$ the cycle COP incline also by $2.67 \%$ and from $P_{1}$ to $P_{2}$ the cycle COP rise also by $1.55 \%$ when the cabinet temperature is $8^{\circ} \mathrm{C}$, this is due to the reduction in pressure loss through capillary tube, which lead to increase the refrigerant mass flow rate through evaporator, in the another word the cycle refrigeration effect increases and the compressor work decreases as excepted. The maximum COP is about 2.7 when the cabinet temperature is $8^{\circ} \mathrm{C}$ and pitch distance is $10 \mathrm{~mm}$. Moreover, It can be seen that as the cycle COP steady up going by approximately average 5\% when the evaporator cabinet temperature rise $1^{\circ} \mathrm{C}$.

Figures 6 to 9 show the effect of pitch distance on the cycle COP for coiled diameters of 50,75, 100 and $125 \mathrm{~mm}$, it can be seen from the figures mentioned above that the increases in pitch distance improving the cycle COP by $5.31 \%, 5.62 \%, 5.91 \%$ and $2.2 \%$ respectively when the cabinet temperature is $8^{\circ} \mathrm{C}$ for the reason mentioned above. From all the figures that inspected above it can be seen that the cycle COP affected by many variables namely pitch distance, evaporator cabinet temperature and capillary tube coiled diameter. The effect of coiled diameter on the cycle COP is shown in figure 10 for the best pitch distance namely $10 \mathrm{~mm}$. It can be seen from the figure that the COP improved significantly by around $7 \%$ as the coiled diameter increases to $100 \mathrm{~mm}$, but the increases in cycle COP seems to be insignificant by roughly $2.5 \%$ when the coiled diameter increases from 100 to $125 \mathrm{~mm}$. This due to that the pressure loss approach to its minimum value when the coiled diameter is 100 $\mathrm{mm}$. It can be seen that as the cycle COP steady increase by around rate $5 \%$ when the evaporator cabinet temperature up going by $1^{\circ} \mathrm{C}$.

It can be seen from the figures 5 to 10 mentioned above that the effect of pitch distance on the cycle COP is insignificant, while the coiled diameter affect the cycle COP strongly as shown in figure 9, maximum COP is about 3.7 when the pitch distance is $10 \mathrm{~mm}$ and the coiled diameter is $125 \mathrm{~mm}$. This is due the minimum reduction in friction loss through capillary tube, and as the friction los decreases the mass flow rate of refrigerant increases and the compression work reduces.

Figure (11) shows the effect of coiled diameter on the calculated mass flow rate of refrigerant at different cabinet temperature, when the pitch distance equals to $10 \mathrm{~mm}$, it can be shown from the figure that the coiled diameter of capillary tube affect the flow of refrigerant through the vapour compression cycle, as the coiled diameter increases by 1 inch $(25 \mathrm{~mm})$ the mass flow of refrigerant approximately increase by $12 \%$ also, this is due to the reduction in friction loss through the capillary tube as the coiled diameter increases. Where it can be seen that as the mass flow of refrigerant steady increase by around rate $4.8 \%$ when the evaporator cabinet temperature incline $1^{\circ} \mathrm{C}$. 
Table (2) shows the sample results of the cycle coefficient of performance (COP) and mass flow rate $\left(m_{R}\right)$ when the evaporator cabinet temperature $=8^{\circ} \mathrm{C}$.

\section{6- CONCLUSIONS:}

1- The coiled diameter of capillary tube affect the cycle COP strongly, as the capillary coiled diameter increases from 25 to $100 \mathrm{~mm}$ the cycle COP increases from 2.8 to 3.7. The increases of coiled diameter more than $100 \mathrm{~mm}$ shows insignificant effect on the cycle COP.

2- The pitch space of capillary tube coiled shows a minor effect on the cycle COP.

3- The mass flow rate of refrigerant increases as the capillary coiled diameter increases.

\section{REFERENCES:}

1. Stoecker, W.F. and Jones, J.W. 1982. Refrigeration and Air Conditioning. 2nd ed. McGraw-Hill: Bogota. Colombia.

2. Kim, S.G., Kim, M.S., and Ro, S.T. 2002. "Experimental Investigation of the Performance of R-22, R-407c and R-410a in Several Capillary Tubes for AirConditioners". Int. J. Refrig. 25: 521-31. (2002)

3. Wei, C.Z., Lin, Y.T., Wang, C.C., and Lev, J.S. 2001. “An Experimental Study of the Performance of Capillary Tubes for R-407c Refrigerant. ASHRAE Trans. 27:634-8. (2001)

4. M.K. Mittal, Ravi Kumar, Akhilesh Gupta "An experimental study of the flow of R407C in an adiabatic helical capillary tube" Department of Mechanical and Industrial Engineering, Indian Institute of Technology, Roorkee 247667, India, international journal of refrigeration $33,840-847$ (2010).

5. Mutalubi Aremu Akintunde "Effect of Coiled Capillary Tube Pitch on Vapour Compression Refrigeration System Performance " Ph.D. Thesis in the Department of Mechanical Engineering, Federal University of Technology, Akure, Nigeria. (2007).

6. Mohd. Kaleem Khan, Ravi Kumar, Pradeep K. Sahoo " Experimental study of the flow of R-134a through an adiabatic helically coiled capillary tube" Department of Mechanical Engineering, Thapar University Patiala, India. (2008).

7. Sukkarin Chingulpitak, Somchai Wongwises "Effects of coil diameter and pitch on the flow characteristics of alternative refrigerants flowing through adiabatic helical capillary tubes" King Mongkut's University of Technology Thonburi, Thailand, International Communications in Heat and Mass Transfer 37, 1305-1311(2010). 
Table 1: Geometries of Test Sections.

\begin{tabular}{|c|c|c|c|c|c|c|c|c|c|c|c|c|c|c|c|}
\hline \multicolumn{16}{|c|}{ Helical coil capillary tube } \\
\hline $\begin{array}{c}\text { Coiled } \\
\text { Diameter } \\
\text { mm (inch) }\end{array}$ & \multicolumn{3}{|c|}{$\begin{array}{c}\operatorname{type}(A) \\
D_{1}=25(1)\end{array}$} & \multicolumn{3}{|c|}{$\begin{array}{c}\text { type }(B) \\
D_{2}=50(2)\end{array}$} & \multicolumn{3}{|c|}{$\begin{array}{c}\text { type }(C) \\
D_{3}=75(3)\end{array}$} & \multicolumn{3}{|c|}{$\begin{array}{c}\operatorname{type}(D) \\
D_{4}=100\end{array}$} & \multicolumn{3}{|c|}{$\begin{array}{c}\operatorname{type}(E) \\
D_{5}=125(5)\end{array}$} \\
\hline \multirow{2}{*}{$\begin{array}{c}\text { Pitches } \\
\text { Distance } \\
\text { mm }\end{array}$} & $P_{1}$ & $P_{2}$ & $P_{3}$ & $P_{1}$ & $P_{2}$ & $P_{3}$ & $P_{1}$ & $P_{2}$ & $P_{3}$ & $P_{1}$ & $P_{2}$ & $P_{3}$ & $P_{1}$ & $P_{2}$ & $P_{3}$ \\
\hline & 6 & 8 & 10 & 6 & 8 & 10 & 6 & 8 & 10 & 6 & 8 & 10 & 6 & 8 & 10 \\
\hline
\end{tabular}

Table 2: Sample Results of COP and $m_{R}$.

\begin{tabular}{|c|c|c|c|c|c|c|c|c|c|c|c|c|c|c|c|}
\hline \multicolumn{10}{|c|}{ Helical coil capillary tube at state of Evaporator Cabinet Temperature $=8^{\circ} \mathrm{C}$} \\
\hline $\begin{array}{c}\text { Coiled } \\
\text { Type }\end{array}$ & \multicolumn{3}{|c|}{ type $(A)$} & \multicolumn{3}{|c|}{ type $(B)$} & \multicolumn{3}{|c|}{ type $(C)$} & \multicolumn{3}{|c|}{ type $(D)$} & \multicolumn{3}{|c|}{ type $(E)$} \\
\hline $\begin{array}{c}\text { Pitches } \\
\text { Distance }\end{array}$ & $P_{1}$ & $P_{2}$ & $P_{3}$ & $P_{1}$ & $P_{2}$ & $P_{3}$ & $P_{1}$ & $P_{2}$ & $P_{3}$ & $P_{1}$ & $P_{2}$ & $P_{3}$ & $P_{1}$ & $P_{2}$ & $P_{3}$ \\
\hline $\mathrm{COP}$ & 2.58 & 2.62 & 2.69 & 2.76 & 2.82 & 2.97 & 3.14 & 3.2 & 3.38 & 3.3 & 3.38 & 3.58 & 3.51 & 3.62 & 3.7 \\
\hline $\mathrm{m}_{\mathrm{R}}\left(\frac{g}{S}\right)$ & & & 1.24 & & & 1.49 & & & 2 & & & 2.4 & & & 2.7 \\
\hline
\end{tabular}

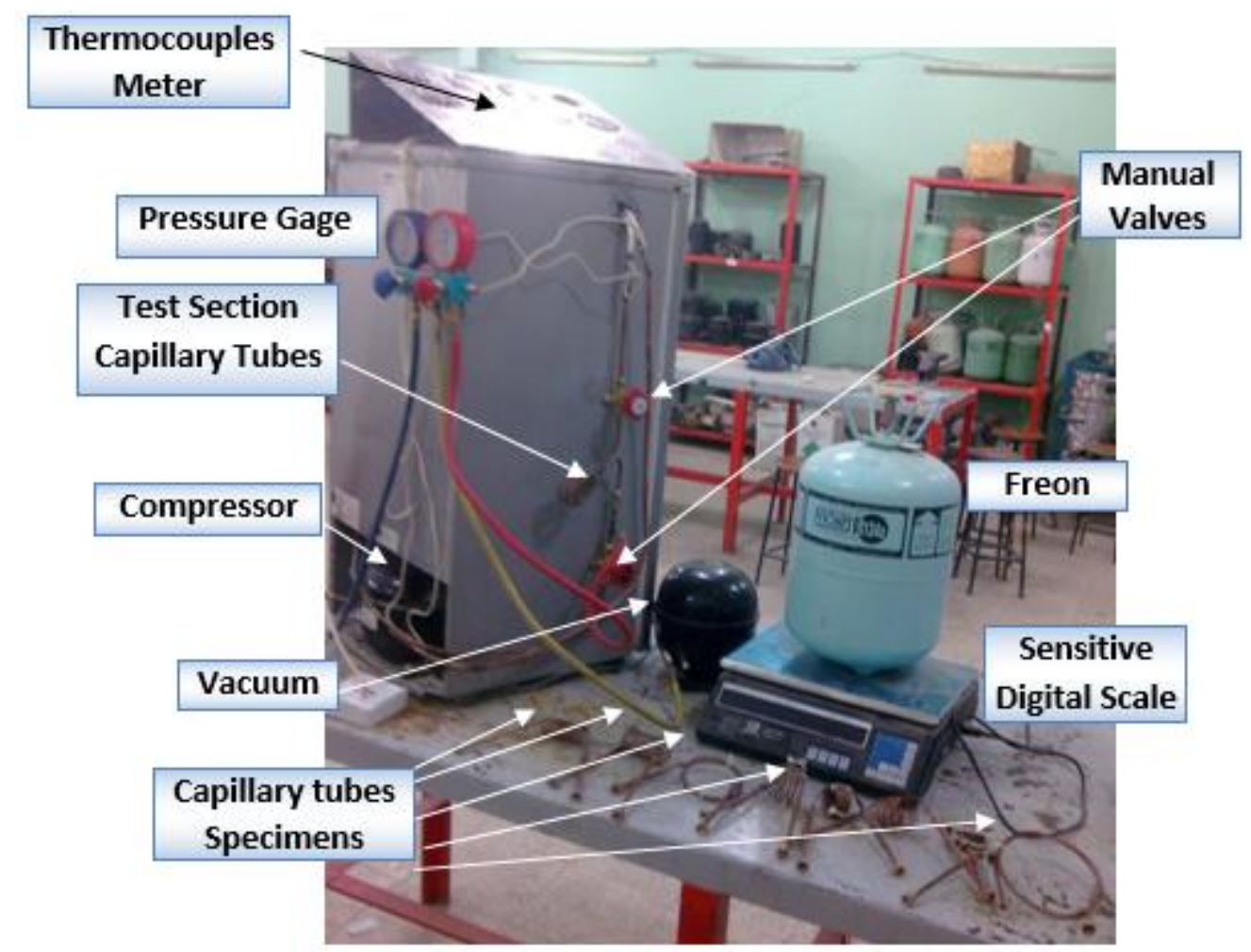

Figure (1): Refrigerator under test. 


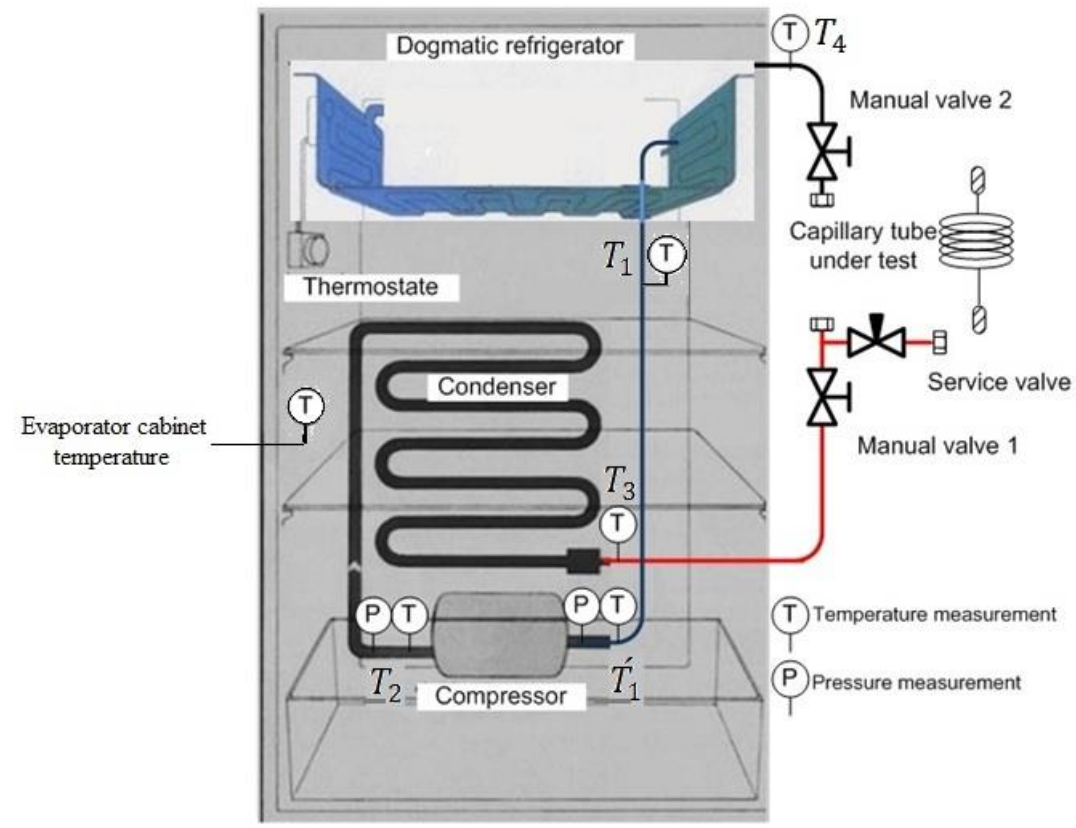

Figure (2): modifications on the $5 \mathrm{ft}^{3}$ refrigerator.

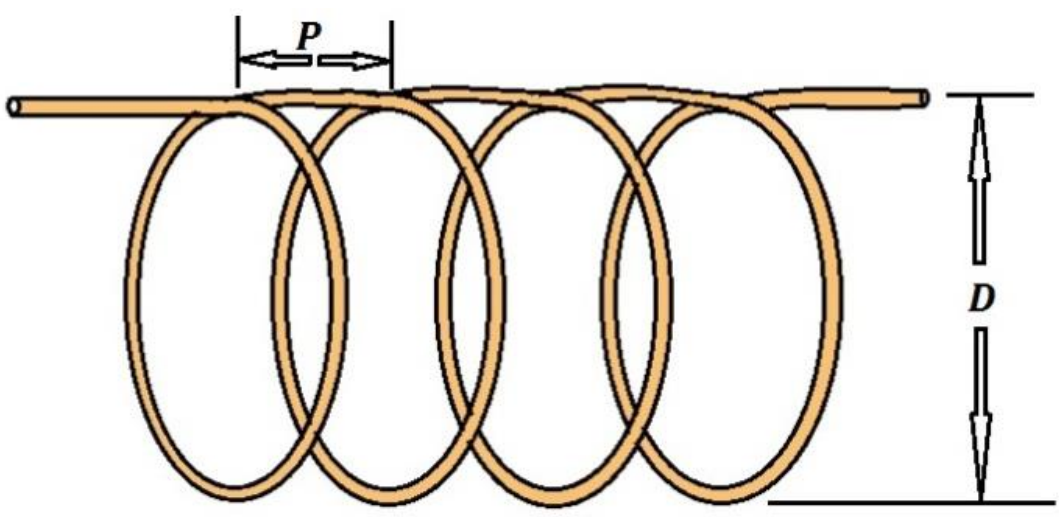

Figure (3): Helical capillary tube under study.

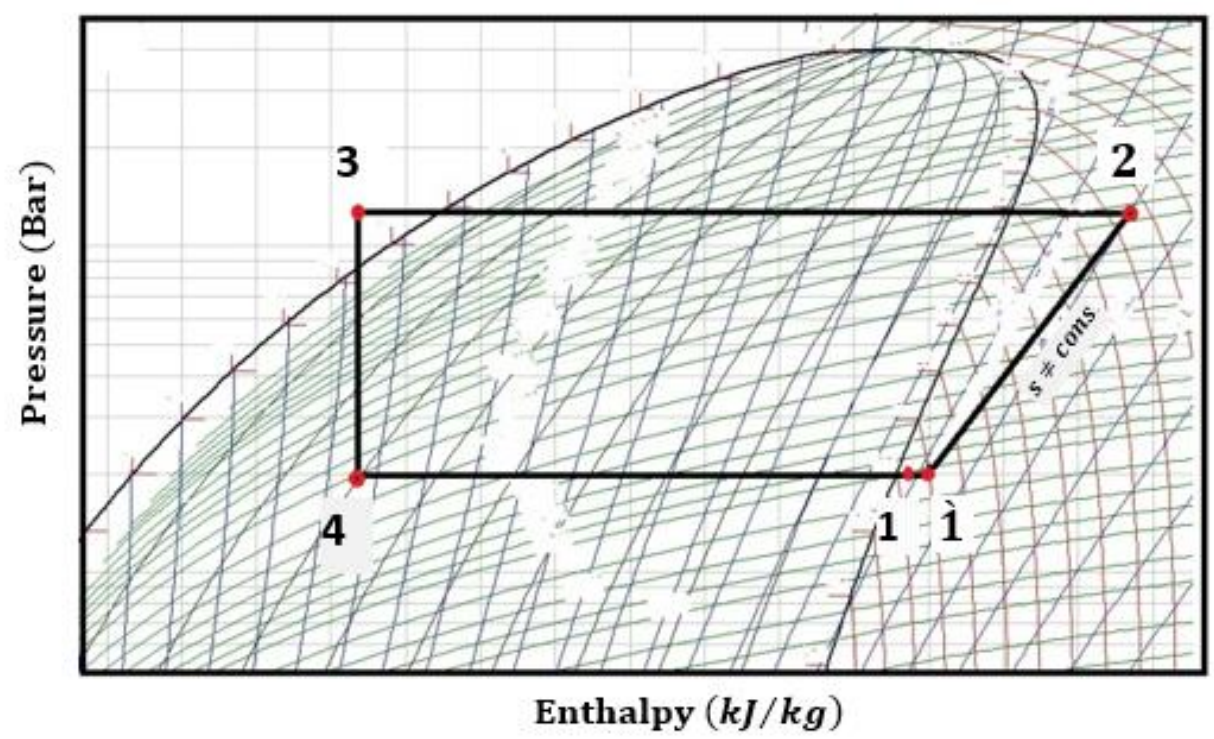

Figure (4): P-h (Pressure-Enthalpy) Diagram of Vapour Compression System. 


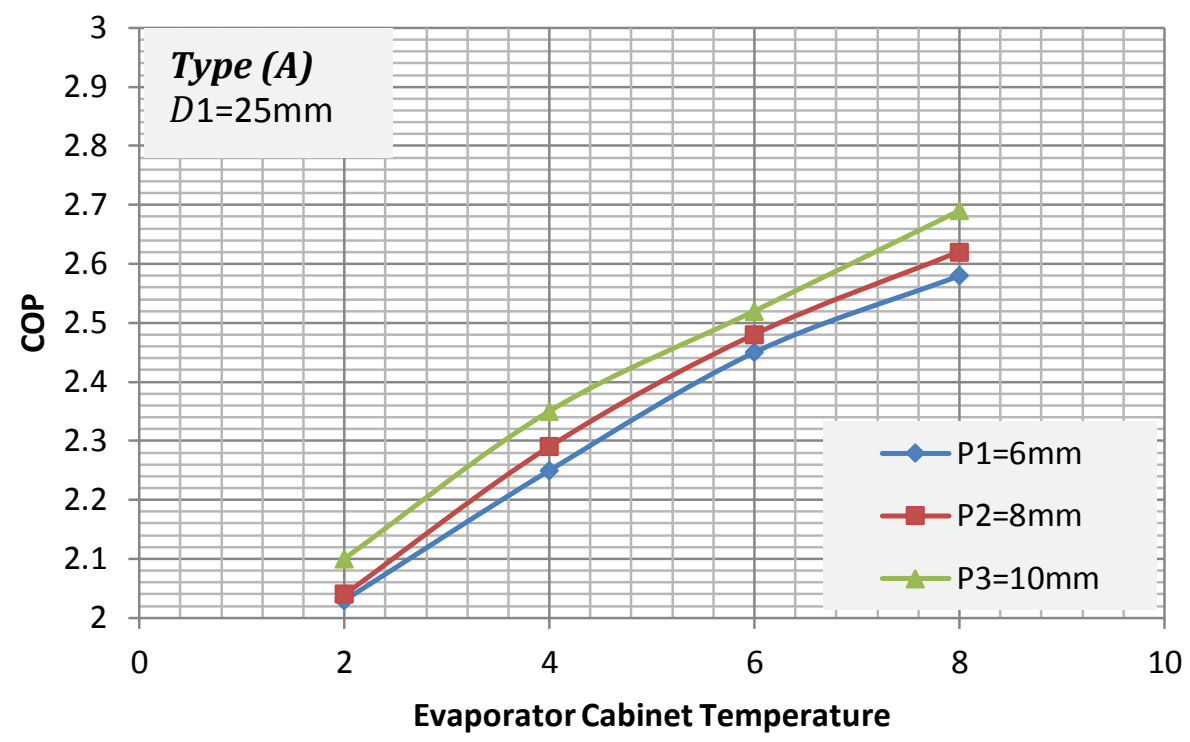

Figure (5): Effect of pitch distance on the cycle COP of refrigeration cycle at different cabinet temperature (Coiled diameter equals $25 \mathrm{~mm}$ ).

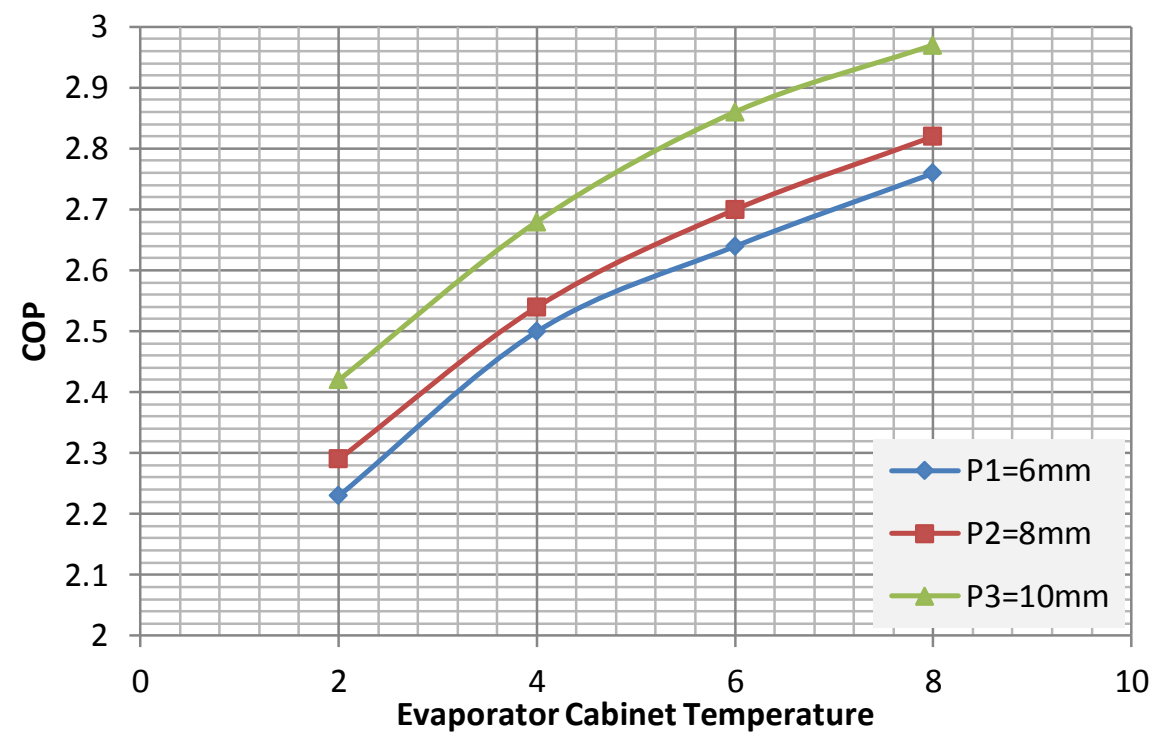

Figure (6): Effect of pitch distance on the cycle $\mathrm{COP}$ of refrigeration cycle at different cabinet temperature (Coiled diameter equals $50 \mathrm{~mm}$ ) 


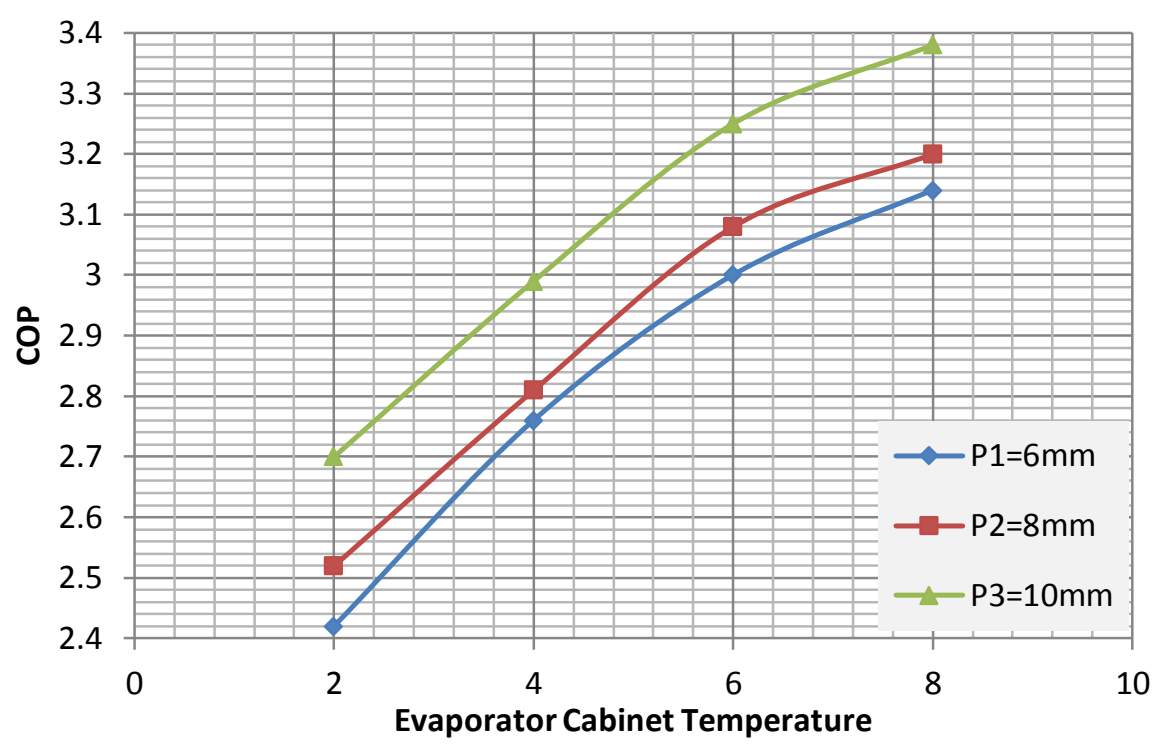

Figure (7): Effect of pitch distance on the cycle COP of refrigeration cycle at different cabinet temperature (Coiled diameter equals $75 \mathrm{~mm}$ ).



Figure (8): Effect of pitch distance on the cycle COP of refrigeration cycle at different cabinet temperature (Coiled diameter equals $100 \mathrm{~mm}$ ). 


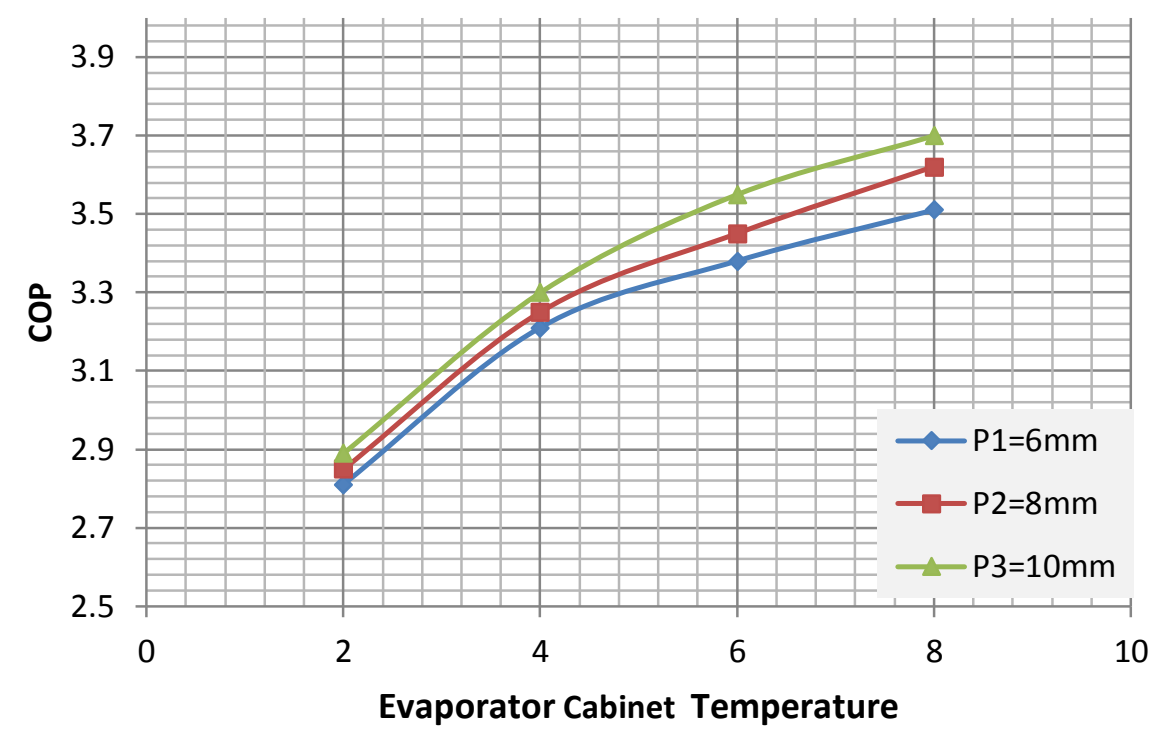

Figure (9): Effect of pitch distance on the cycle COP of refrigeration cycle at different cabinet temperature (Coiled diameter equals $125 \mathrm{~mm}$ ).

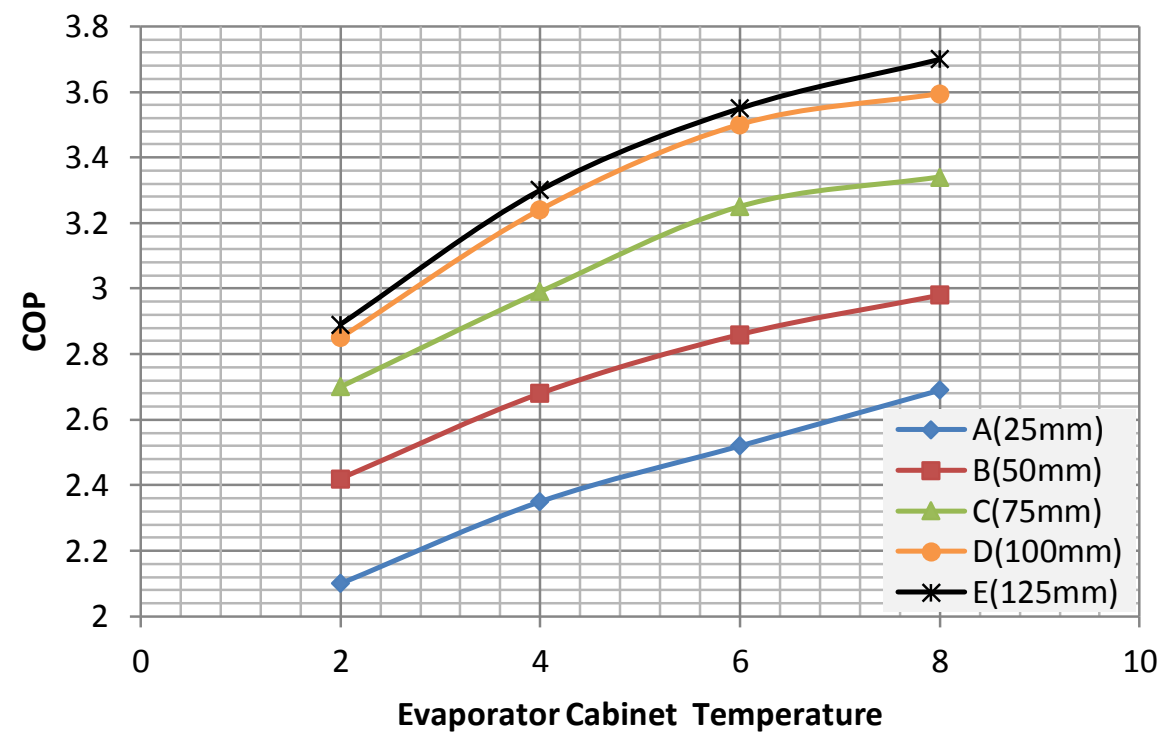

Figure (10): Effect of coiled diameter on the cycle COP at different cabinet temperature (Pitched space equals $10 \mathrm{~mm}$ ). 


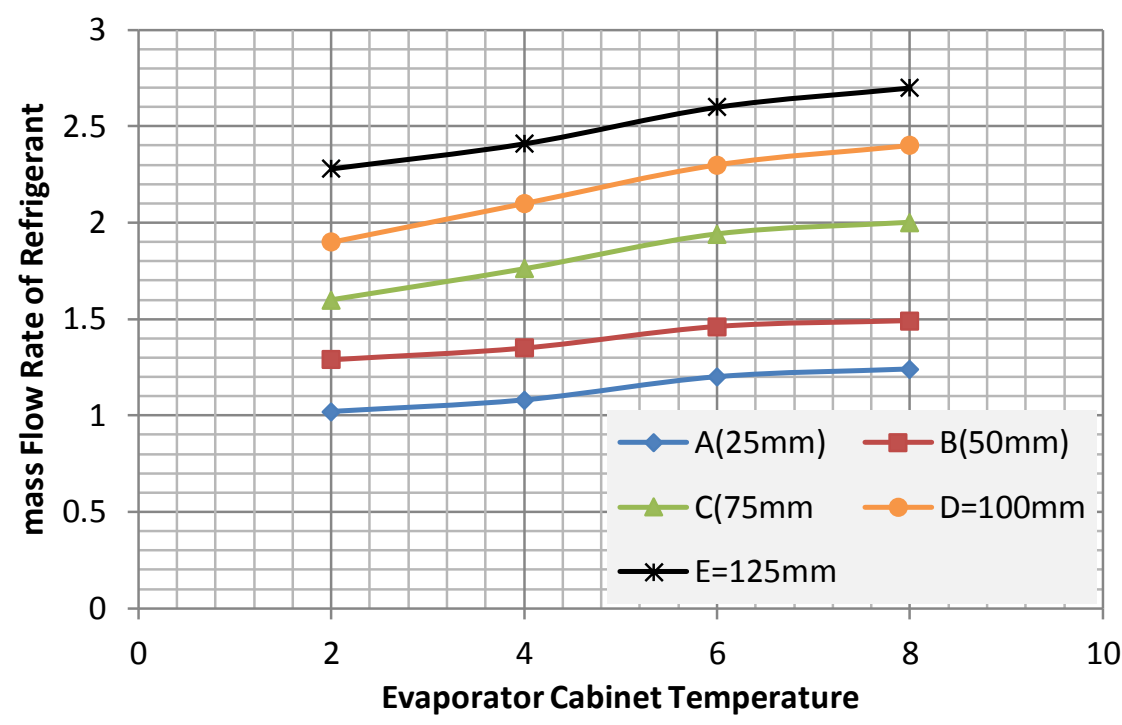

Figure (11): Effect on of coiled diameter the calculated refrigerant mass flow rate at different cabinet temperature (Pitched space equals $10 \mathrm{~mm}$ ). 


\section{دراسة عملية لبيان تأثير شكل الأنبوب الشعري على معامل اداء منظومة تثليج دورة انضغاطية}

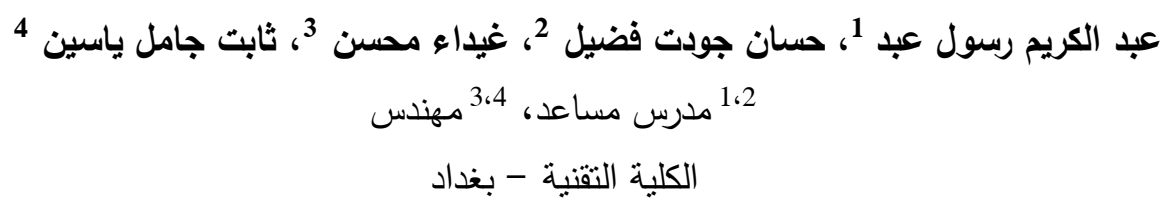

الخلاصة:

تم دراسة تأثير قطر لفة الأنبوب الثعري وكذلك الخطوة بين لفة وأخرى على معامل إداء ثلاجة منزلية سعة 5 قدم ، واستخدمت خمسة أنابيب شعرية قياس كل منها يساوي قياس الأنبوب المستخدم في الثلاجة أصلا، وكان قطر لئر الأنبوب 2 ملم وطول 1500 ملم. شكلت الأنابيب الثعرية للحصول على خمسة أشكال من الأنابيب تختلف بقطر اللفة (D)، حيث تم دراسة خمسة أقطار من اللفات نتراوح من 25 الى 125 ملم بخطوة تساوي 25 ملم. أضافة الى ذللك تم دراسة تأثير المسافة بين لفة وأخرى (P) على معامل أداء الثلاجة وكانت المسافات المدروسة تساوي 6 و و 8 و و 10 ملم. بينت الدراسة ان قطر اللفة (D) يؤثر بشكل كبير على معامل أداء الثلاجة حيث لوحظ زيادة في معامل أداء الثلاجة من

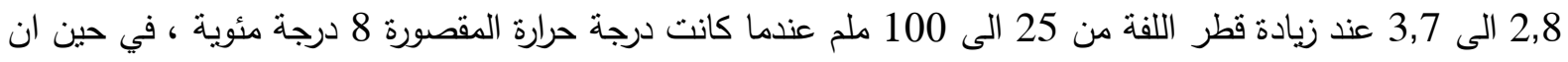
زيادة قطر اللفة اكبر من 100 ملم لا يؤثر بشكل كبير على معامل الأداء. ولوحظ تاثير بسيط على معامل اداء الثلاجة عند تغيير المسافة (P) بين لفة وأخرى. أضافه الى ذللك حصلت زيادة في المعدل التدفق الكتلي بمعدلات تقريبية من

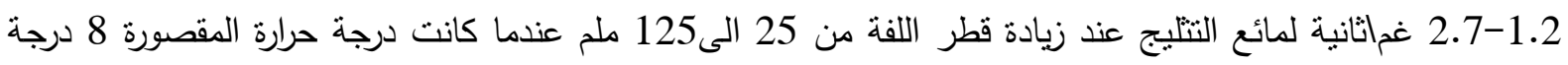
مئوية. ايضا لوحظ وجود علاقة طردية بين درجة حرارة مقصورة التبريد من 2-8 درجة مؤوية مع معدل التدفق الكتلي

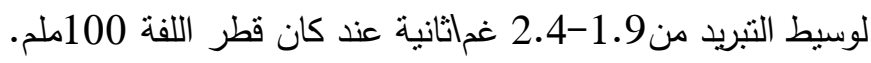
الكلمات الدالة: دورة تتليج انضغاطية، أنبوب شعري، شكل الأنبوب الثعري. 